\title{
NOTCH1 mutations influence survival in chronic lymphocytic leukemia patients
}

\author{
Kerstin Willander ${ }^{1 *}$, Ravi Kumar Dutta ${ }^{2}$, Jonas Ungerbäck², Rebeqa Gunnarsson ${ }^{3}$, Gunnar Juliusson ${ }^{3}$, \\ Mats Fredrikson ${ }^{2}$, Mats Linderholm ${ }^{4}$ and Peter Söderkvist ${ }^{2}$
}

\begin{abstract}
Background: NOTCH1 PEST domain mutations in chronic lymphocytic leukemia have recently been shown to be of prognostic relevance. Both NOTCH1 and $\mathrm{NOTCH} 2$ are constitutively activated in B-cell CLL but not expressed in normal B cells and may be involved in survival and resistance to apoptosis in CLL. We screened for mutations in different parts of both NOTCH1 and NOTCH2 genes and related the changes to survival and other known risk factors.
\end{abstract}

Methods: In a cohort of 209 CLL patients, we used single strand conformation analysis to determine which of the samples carrying the NOTCH mutations and direct dideoxy sequencing was used to determine the exact nucleotide changes. Kaplan-Meier curves and log rank test were used to determine overall survival for NOTCH1 mutated cases and Cox regression analysis was used to calculate hazardous ratios.

Results: In the present study, we found NOTCH1 PEST domain mutations in $6.7 \%$ of the cases. A shorter overall survival was found in patients with NOTCH1 mutations compared to wildtype $(p=0.049)$. Further, we also examined the extracellular and the heterodimerisation domains of the NOTCH1 gene and the PEST domain and heterodimerisation domain of the NOTCH2 gene, but no mutations were found in these regions. NOTCH1 mutations were most commonly observed in patients with unmutated IGHV gene (10/14), and associated with a more aggressive disease course. In addition, NOTCH1 mutations were almost mutually exclusive with TP53 mutations. In the combined group of NOTCH1 (6.7\%) or TP53 (6.2\%) mutations, a significant difference in overall survival compared to the wildtype NOTCH1 and TP53 was found ( $p=0.002)$.

Conclusions: Both NOTCH1 and TP53 mutations seem to be independent predictive markers for worse outcome in CLL-patients and this study emphasizes the contention that NOTCH1 mutations is a novel risk marker.

Keywords: Chronic lymphocytic leukemia, NOTCH1 mutations, TP53 mutations, Prognostic markers

\section{Background}

Chronic lymphocytic leukemia (CLL) is a heterogeneous disease with variable clinical course characterized by a monoclonal progressive accumulation of mature CD5+ B-lymphocytes avoiding apoptosis. Some patients with an indolent disease need no or little treatment while others have a more adverse disease at diagnosis. No common genetic lesion, which causes the disease, has been found [1], but recurrent mutations in CLL involve TP53 and ATM, and novel mutations in the NOTCH1,

\footnotetext{
* Correspondence: kerstin.willander@liu.se

'Department of Clinical and Experimental Medicine, Department of Hematology, County Council of Östergötland, Linköping University, SE-58185 Linköping, Sweden

Full list of author information is available at the end of the article
}

SF3B1, MYD88, BIRC3 and FBXW7 genes have been identified through next generation sequencing [2]. The CLL cases may be divided in two major groups regarding to mutated (M) or unmutated (UM) immunoglobulin heavy chain variable region gene (IGHV) where patients with an unmutated IGHV clone have a more adverse prognosis than patients with mutated IGHV gene [3,4]. By the means of FISH analysis, different chromosomal aberrations as deletion in 11q, 13q, 17p or trisomy 12 are found in about $80 \%$ of tumor cells in the CLLpatients [5].

Recently, NOTCH1 mutations were found to be predictor of poor prognosis in CLL [6-11]. Furthermore a study of Rosati et al. [12] showed that NOTCH1 and 
Table 1 Primer sequences

\begin{tabular}{|c|c|c|c|c|c|}
\hline Gene-exon-segment & Application & Forward primer & Reverse primer & Product size/bp & $\mathrm{T}_{\mathrm{A}} /{ }^{\circ} \mathrm{C}$ \\
\hline Notch1-26-a & PCR/SSCA & AGCCCCCTGTACGACCAGTA & CTTGCGCAGCTCCTCCTC & 283 & 63.5 \\
\hline Notch1-26-b & PCR/SSCA & ACACGGCCAGCAGATGAT & GAGAGTTGCGGGGATTGAC & 231 & 57.1 \\
\hline Notch1- 27 & $\mathrm{PCR} / \mathrm{SSCA}$ & GTGGCGTCATGGGCCTCA & TAGCAACTGGCACAAACAGC & 342 & 63.2 \\
\hline Notch1-34a & $\mathrm{PCR} / \mathrm{SSCA}$ & AACCACCTGCCTGGGATG & CGCATTGACCATTCAAACTG & 232 & 57.1 \\
\hline Notch1-34b & PCR/SSCA & GGGCCCTGAATTTCACTGT & AGGCCCTGGTAGCTCATCAT & 229 & 60 \\
\hline Notch1-34c & PCR/SSCA & GCTGCACAGTAGCCTTGCT & CTGAGCTCACGCCAAGGT & 224 & 58 \\
\hline Notch1-34d & $\mathrm{PCR} / \mathrm{SSCA}$ & ACATCCAGCAGCAGCAAAG & GTGGGACCAGCGAGGATG & 222 & 58 \\
\hline Notch1-34e & PCR/SSCA & CACTATTCTGCCCCAGGAGA & CAGTCGGAGACGTTGGAATG & 234 & 58 \\
\hline Notch1- 34f & PCR/SSCA & ACAGCTACTCCTCGCCTGTG & AAGGCTTGGGAAAGGAAGC & 248 & 58 \\
\hline Notch1-6 & $\mathrm{PCR} / \mathrm{SSCA}$ & GCAGCTGCCCGGGGCCGACA & TCAGGCCTGGCCCATGTGA & 330 & 62 \\
\hline Notch1-7 & PCR/SSCA & ATGCCTGGCCAGGGGCCGT & TCGACTTCTCATCGGTTCT & 273 & 58 \\
\hline Notch1-8 & PCR/SSCA & CCGATGGGGGTGGTGTGCAGT & TGCCCAGCCTCGACTCGGTT & 331 & 63 \\
\hline Notch1-11 & PCR/SSCA & AGTCCTAAGTCTTCCTGTGCC & AGGCCCGCCCTGCCCACT & 325 & 65 \\
\hline Notch1-12 & PCR/SSCA & AGGACTGACCGACACGTG & TCTGAGCACAGTGCAGTCA & 183 & 53 \\
\hline Notch1-13 & $\mathrm{PCR} / \mathrm{SSCA}$ & TGGGCGCTGGGCCTCGGA & ACTGATGTGTCCCCATGA & 268 & 54 \\
\hline Gene-exon-segment & Application & Forward primer & Reverse primer & Product size/bp & $\mathrm{T}_{\mathrm{A}} /{ }^{\circ} \mathrm{C}$ \\
\hline Notch2- 26-1 & $\mathrm{PCR} / \mathrm{SSCA}$ & TTCTCTGCTTCCCCTTACCT & TTAATGCGCAGGTTGGTGT & 250 & 54.1 \\
\hline Notch2- 26-2 & PCR/SSCA & TGGTATTGATGCCACCTGAA & GCCTTGAAGTTCAGAAACCAA & 240 & 54.1 \\
\hline Notch2- 27 & PCR/SSCA & TACCCCCATCTCTCCTCCTC & AATTGTTCCCCCAATTGACA & 250 & 55.2 \\
\hline Notch2-34-1 & PCR/SSCA & TCCCCTGTTGATTCCCTAGA & CACAATGTGGTGGTGGGATA & 249 & 55.2 \\
\hline Notch2-34-2 & PCR/SSCA & GCACTGTGCTTCCCTCAGT & CTGCCTITAGGGATGAGCTG & 298 & 55.2 \\
\hline Notch2-34-3 & $\mathrm{PCR} / \mathrm{SSCA}$ & ACCCATCCTGGCATAGCTC & TAGGCTGGGAGAATGGTCTG & 287 & 55.2 \\
\hline Notch2- 34-4 & $\mathrm{PCR} / \mathrm{SSCA}$ & TITGCCCAGTGTGGCTIT & GGTGATGAACTTGACCACTG & 249 & 57.1 \\
\hline Notch2- 34-5 & PCR/SSCA & ACACCCAGTCACAGTGGTCA & TGTCTCTACACTGGAGGTGGAC & 242 & 61.6 \\
\hline
\end{tabular}

$\mathrm{NOTCH} 2$, together with their ligands Jagged1 -and 2 are constitutively activated in B-CLL cells but not in normal B cells, suggesting that $\mathrm{NOTCH}$ signaling is involved in survival and resistance to apoptosis in CLL.

The NOTCH receptor is a membrane bound protein that consists of an extracellular, transmembrane and intracellular domain that can be released upon ligand interaction and transactivate target genes. The NOTCH signal pathway is activated by a ligand on a neighboring cell and plays an essential role in controlling proliferation, differentiation and survival. Following the receptorligand binding, the $\mathrm{NOTCH}$ receptor first undergoes a $\mathrm{S} 2$ proteolytic cleavage by ADAM proteinase in the extracellular domain, which then is followed by a S3 cleavage by a $\gamma$-secretase complex in the transmembrane domain releasing the intracellular NOTCH domain that translocates to the nucleus where it interacts with a transcription complex and acts as a transcriptional activator for multiple target genes [13]. The C-terminal part of the intracellular domain consists of a PEST region that is important for proteasomal degradation of the $\mathrm{NOTCH}$ receptor by binding to FBXW7, an E3 ubiquitin ligase, to limit duration of the $\mathrm{NOTCH}$ activity. A CT deletion in the $\mathrm{C}$-terminal region results in removal of the PEST domain, a truncated NOTCH protein, and impaired NOTCH degradation and constitutive transcriptional activation of NOTCH target genes in CLL $[7,14]$.

In the present study we have screened for mutations in different parts of both the NOTCH1 and NOTCH2 gene in a cohort of 209 CLL-patients. There is a high structural similarity between $\mathrm{NOTCH} 1$ and $\mathrm{NOTCH} 2$ genes and recent $\mathrm{NOTCH} 2$ gain-of-function mutations are found in B-cell lymphomas [15]. Further, as $\mathrm{NOTCH} 2$ is involved in overexpression of CD23, one of the hallmarks of CLL [16], it prompted us to screen both the NOTCH1 and NOTCH2 genes for genetic alterations. Mutations were only found in the PEST region in the NOTCH1 gene in our cohort and emerged as an independent factor of poor overall survival and disease stage, in addition to TP53 mutations and IGHV gene status.

\section{Methods}

\section{Patients}

In this study, peripheral blood from 209 CLL patients (145 men and 64 women) was collected between 1996 and 2006 at the Department of Hematology, Linköping University Hospital. Mononuclear cells were isolated by 


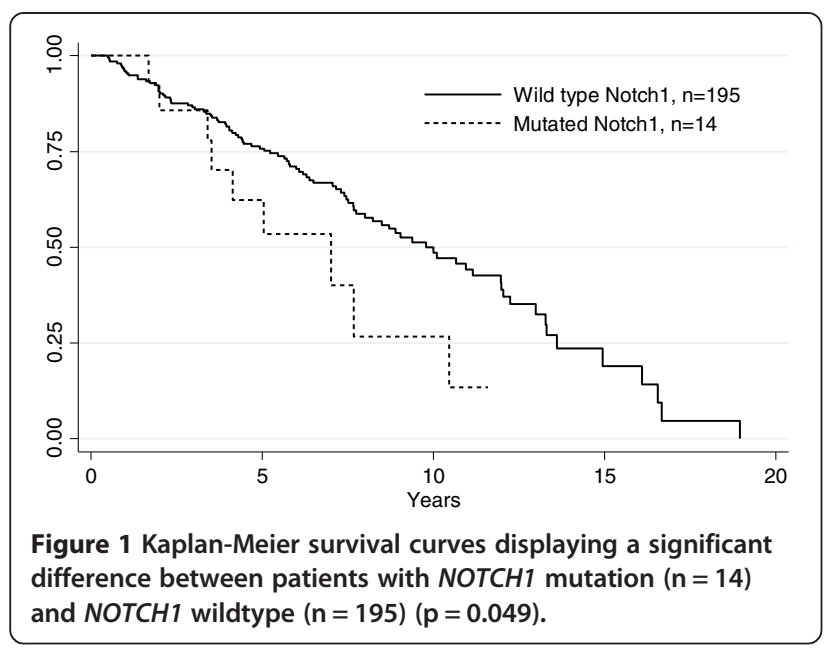

Ficoll-Paque gradient centrifugation and genomic DNA was extracted by proteinase $\mathrm{K}$ digestion and stored frozen until used as earlier described [17]. The samples were collected either at the time of diagnosis or prior to the first treatment. For all patients, follow-up data were available, and for 106 live patients the median follow-up time was 6.8 years (range 1.6-14.9 years). The median age at diagnosis was 62.5 years (range 38.3-87.0 years). The immunophenotype and the Binet staging system were according to the IWCLL guidelines [18]. The

Table 2 Clinical and biological characteristics of the 209 CLL-patients

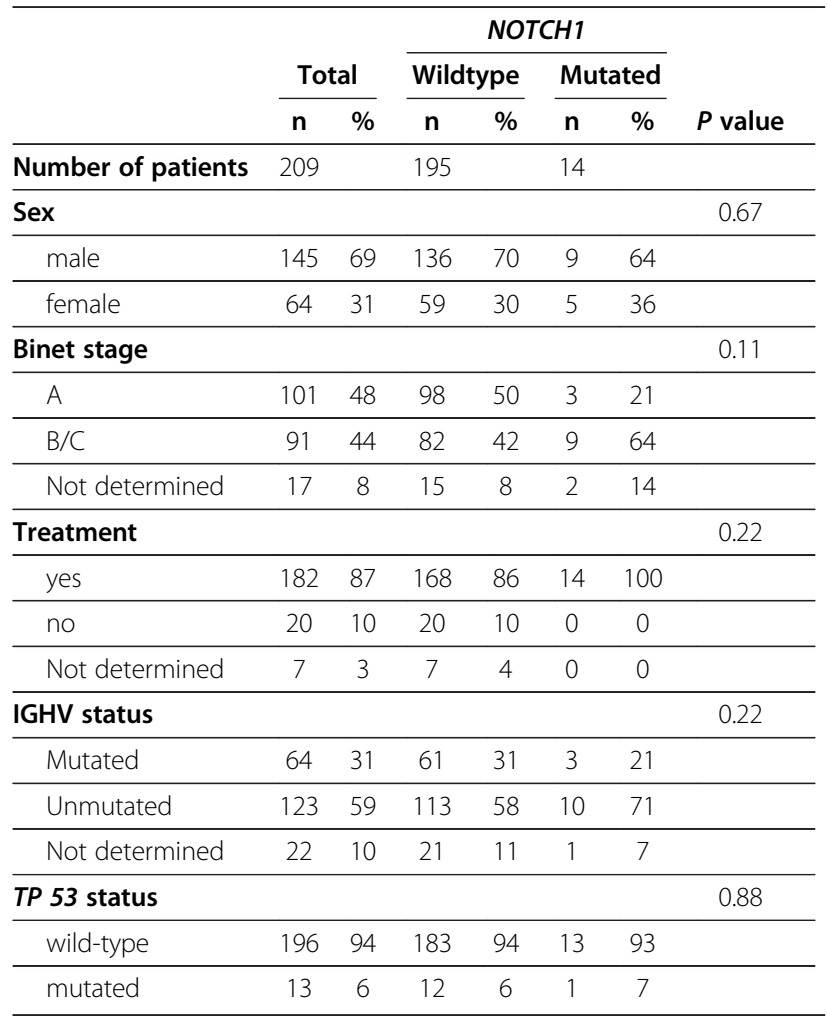

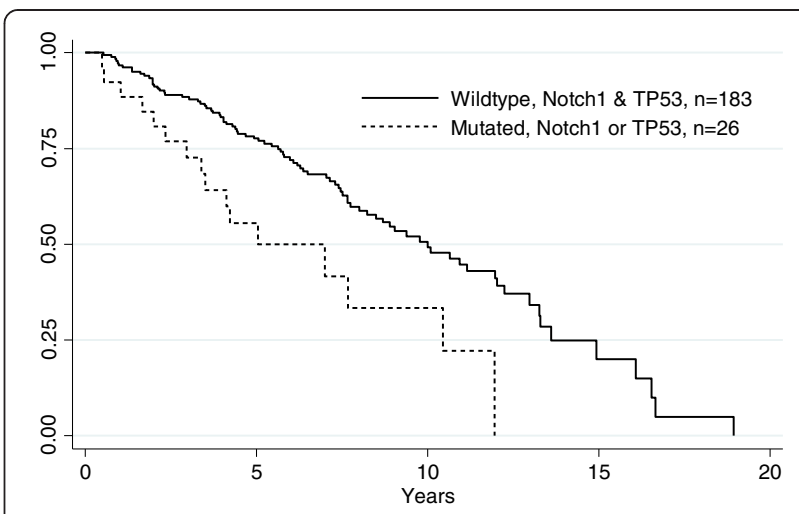

Figure 2 A significant difference in overall survival between patients with $N O T C H 1$ or TP53 mutations $(n=26)$ and CLL with non-mutated NOTCH1 and TP53 $(n=183)(p=0.002)$.

immunoglobulin heavy chain variable region genes (IGHV) and TP53 gene status were analysed and reported in an earlier study [17]. Informed consent was obtained from the patients and the study was approved by the regional ethical committee (Dnr 02-459) in Linköping and conducted in accordance with the ethical guidelines of the Helsinki Declaration.

\section{NOTCH mutation status detection}

The NOTCH1 mutations status were analyzed for the extracellular region (exon 6, 7, 8, 11, 12 and 13), the heterodimerisation domain (exon 26, 27) and the PEST region (exon 34) and the $\mathrm{NOTCH} 2$ was only analyzed for mutations in the heterodimerisation and the PEST domains by PCR amplification followed by single strand conformation analysis (SSCA) according to the original protocol [19] and direct dideoxy sequencing to determine the exact nucleotide change and compared to corresponding $\mathrm{NOTCH} 1$ and $\mathrm{NOTCH} 2$ germline sequence (NM_017617.3 and NM_024408.3 respectively). Primer sequences are shown in Table 1.

\section{TP53 and IGHV gene status detection}

TP53 gene mutation analysis was performed for exons 5-8 (the DNA binding domains) by the PCR-single strand conformation analysis (SSCA) technique and samples displaying mobility shifts were sequenced with the dideoxy termination method to confirm the nucleotide changes.

The IGHV gene mutational status was performed by PCR amplification on genomic DNA by using specific $\mathrm{VH} / \mathrm{JH}$ primers [20], followed by DNA sequencing of both forward and reverse strands. To determine the IGHV gene identity the sequences were aligned by using the IMGT/V-QUEST database (http://imgt.org), $\geq 98 \%$ identity to the corresponding germline sequence was considered as an unmutated IGHV gene. 
Table 3 Analysis for overall survival

\begin{tabular}{|c|c|c|c|c|c|c|c|}
\hline & $\mathrm{N}$ & HR & $95 \% \mathrm{Cl}$ & $P$ & $\mathrm{HR}^{1}$ & $95 \% \mathrm{Cl}$ & $P$ \\
\hline Wildtype NOTCH1 and TP53 & 183 & 1 & & & 1 & & \\
\hline Mutated NOTCH1 or TP53 & 26 & 2.27 & $1.32-3.91$ & 0.003 & 2.16 & $1.25-3.72$ & 0.006 \\
\hline Wildtype NOTCH1 & 195 & 1 & & & 1 & & \\
\hline Mutated NOTCH1 & 14 & 2.04 & $0.98-4.25$ & 0.056 & 1.80 & $0.86-3.76$ & 0.12 \\
\hline Wildtype TP53 & 196 & 1 & & & 1 & & \\
\hline Mutated TP53 & 13 & 2.54 & $1.17-5.54$ & 0.019 & 2.54 & $1.17-5.53$ & 0.002 \\
\hline
\end{tabular}

$H R$, hazard ratio; $\mathrm{Cl}$, confidence interval.

${ }^{1}$ Adjusted for age and sex.

\section{Statistical analysis}

Kaplan-Meier curves were used to show the overall survival and the log-rank test was used to compare the survival between the groups. To calculate hazard ratios (HR) the Cox proportional hazard model (Cox-regression) was used. For all statistical analyses Stata v12.1 was used (StataCorp LP, College Station, TX, USA). P-values less than 0.05 were considered significant. Overall survival was measured from date of diagnosis until the last follow-up or death.

\section{Results and discussion}

NOTCH1 heterozygous mutations in the PEST domain occurred in a frequency of 14 out of 209 patients (6.7\%) in our study. Thirteen of the mutations correspond to a 2-bp frameshift deletion, c.7541_7542delCT and one is a novel GT deletion at c.6988_6989delGT, both generating frameshift mutations, with subsequent stopcodon and truncated proteins eliminating the PEST domain. The Kaplan-Meier curve for the CLL-patients with NOTCH1 mutations revealed a shorter overall survival (OS) compared to NOTCH1 wildtype patients $(\mathrm{p}=0.049)$ (Figure 1). Clinical and biological characteristics of the CLL patients in relation to the NOTCH1 status are summarized in Table 2. Our study showed a similarity to other CLL studies, which have reported NOTCH1 PEST domain mutations in 4.7\% - 12.2\% [6-11].

$\mathrm{T}$ cell acute lymphoblastic leukemia (T-ALL) display high frequency of activating NOTCH1 mutations including the extracellular heterodimerisation domain, in addition to elimination C-terminal PEST region mutations

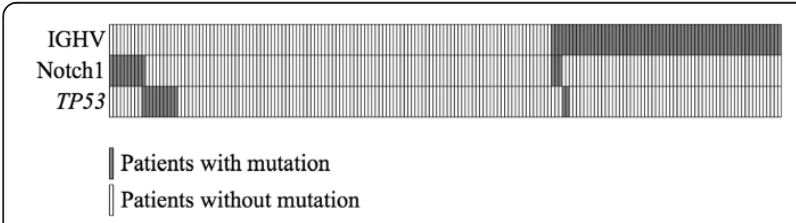

Figure 3 Distribution of NOTCH1 mutations among IGHV gene status and TP53 gene status. Ten of fourteen cases with mutated NOTCHI gene are found in the unmutated IGHV gene group and only one patient has both NOTCH1 mutation and TP53 mutation.
[21]. Studies in head and neck cancer have also identified mutations in the extracellular epiderminal growth factor repeat domain in the NOTCH1 gene [22]. These studies prompted us to screen for mutations in those parts of the NOTCH1 gene, but no mutations could be detected. $\mathrm{NOTCH} 2$ has a role in marginal zone B cell fate decision, similar to the critical role for NOTCH1 in determing the T-cell fate [13]. NOTCH2 mutations are found in the Cterminal part close to the PEST region in splenic marginal zone lymphoma [23,24], but we did not find any mutations in the PEST region or heterodimerisation domain of the NOTCH2 gene in our cohort.

Mutations in the TP53 gene are associated with poor prognosis in CLL [25]. Mutations in the NOTCH1 gene are almost mutually exclusive with mutations in the TP53 gene with or without $17 \mathrm{p}$ or $11 \mathrm{q}$ deletions, only one sample harbored mutations in both NOTCH1 and TP53. Combined, NOTCH1 (6.7\%) and TP53 (6.2\%) mutations represent $12.9 \%$ of the patients in this cohort and indicated a significant worse survival as compared to wildtype NOTCH1 and TP53 (Log rank analysis, $\mathrm{p}=0.002$ ) (Figure 2). NOTCH1 mutations may appear together with trisomy 12 [26,27], and in our cohort, trisomy 12 was found in $15 / 152$ patients by BAC (bacterial artificial chromosome) microarray analysis and two of these carried NOTCH1 mutation; this association was not significant $(\mathrm{p}=0.56)$. By univariate analysis, the $\mathrm{HR}$ for death increased to 2.27 (1.32-3.91; 95\% confidence interval) for tumors mutated in NOTCH1 or TP53 compared to NOTCH1 and TP53 wildtype tumors $(\mathrm{p}=0.003)$ (Table 3$)$. At the molecular level there seems to be an intriguing and complex link between p53 and NOTCH1. P53 induce NOTCH1 expression and seems to initiate an anti-apoptotic feedback mechanism with subsequent increased cell survival that may limit p53 promoting therapy with e.g. nutlins $[28,29]$. $\mathrm{NOTCH}$ signaling blockade by $\gamma$-secretase inhibitors to stimulate apoptosis may be considered to be of therapeutic value at least for wt p53 CLL patients [28].

Among CLL patients with a mutated NOTCH1 gene $10 / 14(71 \%)$ had an unmutated IGHV gene in contrast to $113 / 195$ (58\%) with a wildtype NOTCH1 gene, a difference that did not reach statistical significance $(\mathrm{p}=0.22)$ 
(Figure 3 and Table 2). CLL with NOTCH1 mutations seemed to be more progressive, with a high frequency of unmutated IGHV gene and advanced Binet stages, indicating a more aggressive disease course.

Five patients in this cohort had NOTCH1 mutation at the time of diagnosis. For these patients the median time to first treatment was 101 days (range 21 to 145 days). For the whole group the median time from diagnosis to the first treatment was 438 days (range 0-6021 days). Further and expected, all patients with NOTCH1 mutations identified at diagnosis had the more advanced Binet stages $\mathrm{B}$ and $\mathrm{C}$, a tendency that due to few observations did not reach significance $(\mathrm{p}=0.11)$ (Table 2$)$. The frequency of NOTCH1 mutations is also reported to be significantly higher in Richter syndrome, i.e., a progression of CLL into diffuse large lymphoma with often dismal outcome $[8,30]$, however our cohort contained no information on the prevalence of Richter syndrome.

It is now recommended to perform TP53 mutation analysis in patients with CLL as TP53 mutations occur in about $5 \%$ of cases in absence of $17 p$ deletion and represent an independent prognostic factor associated with worse outcome [31]. CLL patients with 17p deletion and/or TP53 mutations are strongly associated with refractory disease, and also activated NOTCH1 mutations were recently suggested to cause refractoriness to fludarabine $[8,9,32]$.

\section{Conclusions}

Our study confirms other recent reports that NOTCH1 mutation eliminating the PEST domain, has a prognostic value as a novel risk marker in CLL similar to TP53 mutations. Thus both NOTCH1 and TP53 mutation may be an indication for earlier and more active treatment or as an indicator for transplantation therapy.

\section{Competing interests}

The authors declare that they have no competing interests.

\begin{abstract}
Authors' contributions
KW collected data, performed experiments, analyzed and interpreted data, wrote the manuscript; RKD performed experiments, analyzed and interpreted data; JU performed experiments, analyzed and interpreted data; RG performed experiments and interpreted data; GJ interpreted data; MF performed statistical analysis; ML designed experiments; PS designed experiments, wrote the manuscript. All authors were involved in writing the manuscript. All authors read and approved the final manuscript.
\end{abstract}

\section{Acknowledgements}

This study is supported by FORSS grant \#235261.

\section{Author details}

'Department of Clinical and Experimental Medicine, Department of Hematology, County Council of Östergötland, Linköping University, SE-58185 Linköping, Sweden. ${ }^{2}$ Department of Clinical and Experimental Medicine, Linköping University, Linköping, Sweden. ${ }^{3}$ Department of Laboratory Medicine, Stem Cell Center, Hematology and Transplantation, Lund University, Lund, Sweden. ${ }^{4}$ Department of palliative care, Stockholms Sjukhem, Stockholm, Sweden.
Received: 21 December 2012 Accepted: 29 May 2013

Published: 4 June 2013

\section{References}

1. Chiorazzi N, Rai KR, Ferranini M: Chronic lymphocytic leukemia. N Engl J Med 2005, 352:805-815.

2. Wang L, Lawrence MS, Wan Y, Stojanov P, Sougnez C, Stevenson K, Werner L, Sivachenko A, DeLuca DS, Zhang L, Zhang W, Zhang W, Vartanov AR, Fernandes SM, Goldstein NR, Folco EG, Cibulskis K, Tesar B, Sievers QL, Shefler E, Gabriel S, Hacohen N, Reed R, Meyerson M, Golub TR, Lander ES, Neuberg D, Brown JR, Getz G, Wu CJ: SF3B1 and other novel cancer genes in chronic lymphocytic leukemia. N Engl J Med 2011, 365:2497-2506.

3. Damle RN, Wasil T, Fais F, Ghiotto F, Valetto A, Allen SL, Buchbinder A, Budman D, Dittmar K, Kolitz J, Lichtman SM, Schulman P, Vinciguerra VP, Rai KR, Ferrarini M, Chiorazzi N: IgV gene mutation status and CD 38 expression as novel prognostic indicators in chronic lymphocytic leukemia. Blood 1999, 94:1840-1847.

4. Hamblin TJ, Davis Z, Gardiner A, Oscier DG, Stevenson FK: Unmutated IgV $(\mathrm{H})$ genes are associated with a more aggressive form of chronic lymphocytic leukemia. Blood 1999, 94:1848-1854.

5. Döhner H, Stielgenbauer S, Benner A, Leupolt E, Kröber A, Bullinger L, Döhner K, Bentz M, Lichter P: Genomic aberrations and survival in chronic lymphocytic leukemia. N Engl J Med 2000, 343:1910-1916.

6. Sportoletti P, Baldoni S, Cavalli L, Del Papa B, Bonifacio E, Ciurnelli R, Bell AS, Di Tommaso A, Rosati E, Crescenzi B, Mecucci C, Screpanti I, Marconi P, Martelli MF, Di lanni M, Falzetti F: Notch1 PEST domain mutation is an adverse prognostic factor in B-CLL. British Journal of Haematology 2010, 151:404-406.

7. Puente XS, Pinyol M, Quesada V, Conde L, Ordonez GR, Villamor N, Escaramis G, Jares P, Beà S, González-Díaz M, Bassaganyas L, Baumann T, Juan M, López-Guerra M, Colomer D, Tubío JM, López C, Navarro A, Tornador C, Aymerich M, Rozman M, Hernández JM, Puente DA, Freije JM, Velasco G, Gutiérrez-Fernández A, Costa D, Carrió A, Guijarro S, Enjuanes A, et al: Whole genome sequencing identifies recurrent mutations in chronic lymphocytic leukemia. Nature 2011, 475:101-105.

8. Fabbri G, Rasi S, Rossi D, Trifonov V, Khiabanian H, Ma J, Grunn A, Fangazio M, Capello D, Monti S, Cresta S, Gargiulo E, Forconi F, Guarini A, Arcaini L, Paulli M, Laurenti L, Larocca LM, Marasca R, Gattei V, Oscier D, Bertoni F, Mullighan CG, Foá R, Pasqualucci L, Rabadan R, Dalla-Favera R, Gaidano G: Analysis of the chronic lymphocytic leukemia coding genome: role of NOTCH1 mutational activation. J Exp Med 2011, 208:1389-1401.

9. Rossi D, Rasi S, Fabbri G, Spina V, Fangazio M, Forconi F, Marasca R, Laurenti L, Bruscaggin A, Cerri M, Monti S, Cresta S, Famà R, De Paoli L, Bulian P, Gattei V, Guarini A, Deaglio S, Capello D, Rabadan R, Pasqualucci L, DallaFavera R, Foà R, Gaidano G: Mutations of Notch1 are an independent predictor of survival in chronic lymphocytic leukemia. Blood 2012, 119:521-529.

10. Shedden K, Li Y, Quillette P, Malek SN: Characteristics of chronic lymphocytic leukemia with somatically acquired mutations in exon 34 . Leukemia 2011, 26:1108-1110.

11. Mansouri L, Cahill N, Gunnarsson R, Smedby KE, Tjönnfjord E, Hjalgrim H, Juliusson G, Geisler C, Rosenquist R: NOTCH1 and SF3B1 mutations can be added to the hierarchical prognostic classification in chronic lymphocytic leukemia. Leukemia 2013, 27:512-514

12. Rosati E, Sabatini R, Rampino G, Tabilio A, Di lanni M, Fettucciari K, Bartoli A Coaccioli S, Screpanti I, Marconi P: Constitutively activated Notch signaling is involved in survival and apoptosis resistance of B-CLL cells. Blood 2009, 113:856-865.

13. Radtke F, Wilson A, Mancini SJC, Robson MacDonald H: Notch regulation of lymphocyte development and function. Nature Immunology 2004, 5:247-253.

14. Palomero T, Lim WK, Odom DT, Sulis ML, Real PJ, Margolin A, Barnes KC, O'Neil J, Neuberg D, Weng AP, Aster JC, Sigaux F, Soulier J, Look AT, Young RA, Califano A, Ferrando AA: Notch1 directly regulates c-MYC and activates a feed-forward-loop transcriptional network promoting leukemic cell growth. PNAS 2006, 103:18261-18266.

15. Lee SY, Kumano K, Nakazaki K, Sanada M, Matsumoto A, Yamamoto G, Nannya Y, Suzuki R, Ota S, Ota Y, Izutsu K, Sakata-Yanagimoto M, Hangaish A, Yagita H, Fukayama M, Seto M, Kurokawa M, Ogawa S, Chiba S: Gain-offunction mutations and copy number increases of Notch2 diffuse large B-cell lymphoma. Cancer Science 2009, 100:920-926. 
16. Hubmann R, Schwarzmeier JD, Sheta M, Hilgarth M, Duechler M, Dettke M, Berger R: Notch2 is involved in overexperssion of CD23 in B-cell chronic lymphocytic leukemia. Blood 2002, 99:3742-3747.

17. Willander K, Ungerbäck J, Karlsson K, Fredrikson M, Söderkvist P, Linderholm M: MDM2 SNP309 promoter polymorphism, an independent prognostic factor in chronic lymphocytic leukemia. European Journal of Haematology 2010, 85:251-256.

18. Hallek M, Cheson BD, Catovsky D, Caligaris-Cappio F, Dighiero G, Döhner H, Hillmen P, Keating MJ, Montserrat E, Rai KR, Kipps TJ: Guidelines for diagnosis and treatment of chronic lymphocytic leukemia: a report from an international workshop on chronic lymphocytic leukemia updating the national cancer institute working group 1996 guidelines. Blood 2008, 111:5446-5456.

19. Orita M, Suzuki Y, Sekiya T, Hayashi K: Rapid and sensitive detection of point mutations and DNA polymorphism using the polymerase chain reaction. Genomics 1989, 5:874-879.

20. van Dongen JJ, Langerak AW, Brüggemann M, Evans PA, Hummel M, Lavender FL, Delabesse E, Davi F, Schuuring E, García-Sanz R, van Krieken JH, Droese J, González D, Bastard C, White HE, Spaargaren M, González M, Parreira A, Smith JL, Morgan GJ, Kneba M, Macintyre EA: Design and standardization of PCR primers and protocols for detection of clonal immunoglobulin and T-cell receptor gene recombinations in suspect lymphoproliferations: report of BIOMED-2 Concerted Action BMH4-CT98 -3936. Leukemia 2003, 17:2257-2317.

21. Weng AP, Ferrando AA, Lee W, Morris JP 4th, Silverman LB, Sanchez-Irizarry C, Blacklow SC, Look AT, Aster JC: Activating mutations of NOTCH1 in human T cell acute lymphoblastic leukemia. Science 2004, 306:269-271.

22. Stransky N, Egloff AM, Tward AD, Kostic AD, Cibulskis K, Sivachenko A, Kryukov GV, Lawrence MS, Sougnez C, McKenna A, Shefler E, Ramos AH, Stojanov P, Carter SL, Voet D, Cortés ML, Auclair D, Berger MF, Saksena G, Guiducci C, Onofrio RC, Parkin M, Romkes M, Weissfeld JL, Seethala RR, Wang L, Rangel-Escareño C, Fernandez-Lopez JC, Hidalgo-Miranda A, Melendez-Zajgla J, et al: The mutational landscape of head and neck squamous cell carcinoma. Science 2011, 333:1157-1160.

23. Rossi D, Trifonov V, Fangazio M, Bruscaggin A, Rasi S, Spina V, Monti S, Vaisitti $T$, Arruga F, Famà R, Ciardullo $C$, Greco $M$, Cresta $S$, Piranda $D$, Holmes A, Fabbri G, Messina M, Rinaldi A, Wang J, Agostinelli C, Piccaluga PP, Lucioni M, Tabbò F, Serra R, Franceschetti S, Deambrogi C, Daniele G, Gattei V, Marasca R, et al: The coding genome of splenic marginal zone lymphoma: activation of NOTCH2 and other pathways regulating marginal zone development. J Exp Med 2012, 209:1537-1551.

24. Kiel MJ, Velusamy T, Betz BL, Zhao L, Weigelin HG, Chiang MY, HuebnerChan DR, Bailey NG, Yang DT, Bhagat G, Miranda RN, Bahler DW, Medeiros $\sqcup$, Lim MS, Elenitoba-Johnson KS: Whole-genome sequencing identifies recurrent somatic NOTCH2 mutations in splenic marginal zone lymphoma. J Exp Med 2012, 209:1553-1565.

25. Zenz T, Kröber A, Scherer K, Häbe S, Bühler A, Benner A, Denzel T, Winkler D, Edelmann J, Schwänen C, Döhner H, Stilgenbauer S: Monoallelic TP53 inactivation is associated with poor prognosis in chronic lymphocytic leukemia: results from a detailed genetic characterization with long-term follow-up. Blood 2008, 112:3322-3329.

26. Baletti $\vee$, Bottoni A, Palamarchuk A, Alder H, Rassenti LZ, Kipps TJ: Notch1 mutations in CLL associated with trisomy 12. Blood 2012, 119:329-331.

27. Del Guidice I, Rossi D, Chiaretti S, Marinelli M, Tavolaro S, Gabrielli S, Laurent L, Marasca R, Rasi S, Fangazio M, Guarini A, Gaidano G, Foà R: Notch1 mutations in +12 chronic lymphocytic leukemia (CLL) confer and unfavorable prognosis, induce a distinctive transcriptional profiling and refine the intermediate prognosis of +12 CLL. Haematologica 2012, 97:437-441.

28. Secchiero P, Melloni E, di lasio MG, Tiribelli M, Rimondi E, Corallini F, Gattei $\checkmark$, Zauli G: Nutlin-3 up-regulates the expression of Notch1 in both myeloid and lymphoid leukemic cells, as part of negative feedback antiapoptotic mechanism. Blood 2009, 113:4300-4308.

29. Paolo Dotto G: Crosstalk of Notch with p53 and p63 in cancer growth control. Nature Rev. Cancer 2009, 9:587-595.

30. Rossi D, Rasi S, Spina V, Fangazio M, Monti S, Greco M, Ciardullo C, Famà R, Cresta S, Bruscaggin A, Laurenti L, Martini M, Musto P, Forconi F, Marasca R, Larocca LM, Foà R, Gaidano G: Different impact of NOTCH1 and SF3B1 mutations on the risk of chronic lymphocytic leukemia transformation to Richter syndrome. British Journal of Haematoloy 2012, 158:426-229.
31. Pospisilova S, Gonzalez D, Malcikova J, Trbusek M, Rossi D, Kater AP, Cymbalista F, Eichhorst B, Hallek M, Döhner H, Hillmen P, van Oers M, Gribben J, Ghia P, Montserrat E, Stilgenbauer S, Zenz T: ERIC recommendations on TP53 mutation analysis in chronic lymphocytic leukemia. Leukemia 2012, 26:1458-1461.

32. Zenz T, Gribben JG, Hallek M, Döhner H, Keating MJ, Stielgenbauer S: Risk categories and refractory CLL in era of chemoimmunotherapy. Blood 2012, 119:4101-4107.

doi:10.1186/1471-2407-13-274

Cite this article as: Willander et al:: NOTCH1 mutations influence survival in chronic lymphocytic leukemia patients. BMC Cancer 2013 13:274.

\section{Submit your next manuscript to BioMed Central and take full advantage of:}

- Convenient online submission

- Thorough peer review

- No space constraints or color figure charges

- Immediate publication on acceptance

- Inclusion in PubMed, CAS, Scopus and Google Scholar

- Research which is freely available for redistribution

Submit your manuscript at www.biomedcentral.com/submit
C Biomed Central 